\title{
Perception of Genetics by Using of Semantic Differential at High School Students: Preliminary Results
}

\author{
Jana Vlckova ${ }^{1}$, Milan Kubiatko ${ }^{2 *}$ \\ ${ }^{1}$ Masaryk University, Faculty of Education, Department of Education, Brno, CZECH REPUBLIC \\ 2 University of Zilina, Faculty of Humanities, Department of Pedagogical Studies, Zilina, SLOVAKIA
}

Received 25 June 2017 • Revised 12 September 2017 • Accepted 10 October 2017

\begin{abstract}
Genetics is one of the very quickly developing disciplines and it influences all living people. Attitudes and perception of this field of science can influence motivation to studying genetics and it can create current or future participation in this topic. The main aim was to find out what high school students perceptions were of genetics by the using of semantic differential. The sample size was created by 102 students. The research tool was semantic differential included 20 seven points' pairs of adjectives. Data was analysed by the methods descriptive (mean score), inferential (analysis of variance) and also multidimensional statistics (factor analysis). The perception of genetics is slightly positive and in the conclusion are suggested the proposals of further research.
\end{abstract}

Keywords: genetics, high school students, perception, semantic differential

\section{INTRODUCTION}

Heredity, genetic disease, genetically modified organisms, animal cloning, fingerprinting, gene therapy and the study of stem cells belong to the field of genealogy. Genealogy and all the above listed genetic fields belong to a deeply investigated field of study. New knowledge and findings in this field of science continues to have meaningful implications for individuals and society (Lanie et al. 2004). This creates requirements for improving the level of genetic education more than ever before. Additionally, the idea of genetic literacy is becoming more and more important as advancements are made. These applications in genetic technologies are deeply rooted with human life (Shea, Duncan \& Stephenson 2015). The mass media inform us about genetics-related issues. People should be able to deal with these information and critically think about them. Thus, it is necessary to be aware about basic genetics concepts (Gili 2001). Moreover, students and peoples need to understand to genetics-related topics for dealing with ethical and social aspect of genetics (Saka et. al 2006). Results of study conducted by Zande (2009) showed that students use emotive and intuitive reasoning as well as rationalistic, but they are not aware of this. In real life, there are questionable issues which are connected with genetics. People use to make their decision according to personal or moral grounds which are different than scientific arguments. Students are future citizens and they should be aware of value of scientific knowledge and their importance for their personal life. Genetic education should prepare students for making decisions connected with moral dilemmas in genetics (Ratcliffe \& Grace 2003). However, this fundamental topic has a big impact on society and its moral reasoning. Genetics and all other connected fields associated with these issues often separates people to enthusiast and adversary. The ethical and moral aspect of genetics and its impact on human society should be discussed in every aspect of the educational system. Attitudes and perceptions of this field of science can influence an individual's motivation to studying genetics. This can however create further interest and participation in genealogy. Problems that occur in enthusiasm for studying genetics are typically related to its demand. Genetics is one of the most difficult topics both for students and teachers to grasp (Finley, Stewart \& Yarroch 1982; Bahar, Johnstone \& Hansell 1999). Furthermore, genetics is a challenging and intellectual topic that often has many perceived misconceptions and confusions compared to other fields of biology (Cimer 2012). 


\section{Contribution of this paper to the literature}

- The semantic differential produced valid and reliable results.

- The overall attitude to genetics was identified to be slightly positive.

- There was not statistically significant difference in perception of genetics with the respect to religiosity.

\section{THEORETICAL BACKGROUND}

Attitudes defined from the psychological point of view are relatively permanent psychological systems expressing relationship of a person compared to the surround world. Attitudes occupy an important place in structure of personality. These include two main components: First is the relationship to activity and secondly is the subjective condition of an individual (mainly the emotional aspect (Eagly \& Chaiken 1998)). Other authors describe attitudes as the tendency of organisms to respond positively or negatively to individuals, subjects or situations (Morgan 1961). Perception, thinking and the behaviour of individuals are influenced by attitudes. Besides, people commonly try to identify or copy attitudes of other people. Knowledge of people' attitudes in a particular situation can make the surrounding world incomprehensible. People adjust their thinking and behaviour according to attitudes of other people. Additionally, peoples' behaviour can be manipulated by changing and influencing their state of mind. Furthermore, human attitudes are an essential factor affecting the development of social groups. Approaches to social groups including larger social groups can be mutually leveraged by collaboration and conflict (Perkins, Hughey \& Speer 2002). These authors emphasize the psychological function of attitudes. Attitudes contribute to the integration of personality and to the establishment of inward balance. Functions of attitudes are knowledge-based (organisation and processing of information), utilitarian (behaviour leading to increasing amount of rewards and decreasing amount of punishments), social identity (enabling expression of values and identifying with particular social group) and sustaining self-esteem (create appropriate reaction to negative and positive stimuli). Attitudes are connected with interest. Hidi (2006) claimed that interest influence achievement and motivation in learning process. Success in teaching theory is unfolds from interest of students in the school subject (or particular topic). This interest is dependent on the individual's attitude towards his or her school subject or topic (Jones, Howe \& Rua 2000).

The above mentioned information proves that an individual's attitude is interconnected with their motivation to study. Success in learning processes is derived from all attitudes, motivations and interests. Moreover, these concepts are interrelated. Therefore, revealing attitudes, operating and using them during the learning process can be pivotal moment in their education.

\section{THE CURRENT STATE OF LITERATURE}

The research studies relating to problems in genetic perception do not belong among modern valid research. A similar trend is readily available to read in the study of Gul \& Sozbilir (2015), who analysed more than 600 research studies and validated that most often were regarded to misconceptions in cell education, ecology, environmental attitudes and others. We can also familiarize with studies relating to the knowledge of genetics (e.g. Sorgo et al. 2014). However, in the next paragraph attentions will be shifted to the general aim of misunderstandings and problems in genetic perception. Researchers Jallinoja \& Aro (2000) focused their study on Finnish public attitudes about gene testing and the influence of knowledge on this testing. Study results showed approval of gene testing among majority of the population. Subsequently, it was indicated that over half of the respondents consider genetic testing as a realistic possibility. Many of them were afraid and worried with genetic testing. Furthermore, studies revealed the connection between knowledge and attitudes, but opposite attitudes did not simply contribute to this explicit disagreement. People with less knowledge about genetics had more of a problem with choosing the other viewpoint to this topic. Compared with those having a lower level of knowledge, people with more education unveiled both positive and negative mind-sets and attitudes. Simply, individuals who are more educated showed more scepticism when questioned with genetics. Authors require more informed individuals in general and they would like to highline the crucial role of the educational system, specifically the educational curriculum and its imperfections.

Chabalengula, Mumba \& Chitiyo (2011) published research concerning people's attitudes towards biotechnological processes among American elementary education middle school teachers. Authors use questionnaires and surveys utilizing the Likert scale. These quantitative attitudes were quite diverse in opinion when relating to biotechnology. Majority of these pre-serviced teachers approved of the genetic modification of microorganisms and plants. On the other hand most of them disapproved of utilizing this process when regarding the manipulation of human and animal genes. Aro et al. (1997) tested human acceptance of genetic testing in the general population. He focused on differences according to age, education and gender. Genetics testing was 
approved by the majority of the general population. Younger people proved more supportive. Their thinking and acceptance to be profound when pertaining to genetic testing. In contrast, these people were more afraid when it came to the misuse of tests and their results. The strongest group that agreed with compulsory genetic testing were men between 45-69 years of age with only a basic education compared other individuals asked. The individuals who achieved a university degree showed a more objective stance towards genetic testing. These people also showed a predominant fear of eugenics contrasting the other educated groups. Over all the main contributing factors to the attitude on genetic testing and genetically modified organisms were age, sex and level of obtained post graduate education. Jurkiewicz et al. (2014) published research about people's emotional perception based on young people who completed secondary school specialized in the genetic modification of organisms (GMO) and genetically modified foods (GMF). Authors were alerted lack of knowledge pertaining GMO's. Most students were against the cultivation of GM plants and the breeding of GM animals on their own personal farms and land. Genetically modified organisms mean big business for schools and large corporations. Regrettably, students did not see the obvious benefits when concerned with large populations and sustainability. The similar researches were realized by Prokop et al (2007), authors found a significant positive correlation between attitudes and the level of knowledge among Slovakian university students. Females in the research showed poorer knowledge and lower acceptance of genetically engineered products than did males. Overall, Slovakian students have poor knowledge and numerous misunderstandings about what genetic engineering means. Usak et al. (2009) examined statistically significant correlation between the level of biotechnology knowledge and the subdimensions of attitudes toward biotechnology. Authors found no statistically significant difference between high school and university students' knowledge of biotechnology. In contrast, university students showed more positive attitudes toward biotechnology than did high school students. Bal, Samanc1 \& Bozkurt (2007) examine a student's knowledge and attitude when faced with genetic engineering. Students expressed adjustable attitudes to genetic engineering depending on the species of organism and the objectiveness of the study. Furthermore, most students' negative perceptions and risky attitudes changed as they became educated on the matter. Overall students' attitudes to genetics were positive. Most of the respondents regard genetic engineering as an opportunity. Animal genetic engineering was seen as a positive opportunity for people and the future of civilization. In spite of these possible benefits, students did not want to agree with animal genetic engineering. Student revealed positive attitudes to planed genetic engineering when medical professionals were present. In contrast, students had negative attitudes to other type biological plant engineering. Other authors Ceyhan \& Sahin (2014) had an ethical approach relating to genetic topics among preservice science teachers. This also applies to morals and its effect on a mankind. Researchers pointed an association between ethical decisions and idealistic and relativistic ways of thinking. Definitely, topics like genetically modified organisms, cloning and legal regulations concerning genetic applications were linked with moral values. Results showed a positive correlation between GMO's disruptive impact on human health. They recommended labelling GMO products in shops and importance of teaching these topics in school. Other positive relationships were identified. One of which is making individual genetics profile for institutions accessible. This reiterates that human cloning should be supported and allowed for biotechnological research when helping people.

Bahri, Suryawati \& Osman (2014) research found that biotechnology literacy among secondary school students from Malaysia was intermediate. These findings showed that overall students have what we describe as a medium level of knowledge, perception, and attitude towards biotechnology.

\section{AIMS AND RESEARCH QUESTIONS}

This study contributed to the discovery of pupil's attitudes to genetics and as a current and progressive field of science. As well as the influence of independent variables like gender, religiosity and the success of students were the aims of the research. Our research was using the semantic differential, which is a relatively uncommon technique to measure and access the conditions of Middle Europe. Relating to this fact our study the character of pilot studies and the results are preliminary.

On the basis of our targets the following research questions were formulated:

1. What is general students' attitude to genetics?

2. Is there an influence based on gender to the attitude of genetic research?

3. Is there an influence based on religiosity to the attitude of genetic research?

4. Does grade level influence students' attitudes to genetics? 
Table 1. Cronbach alpha for dimensions

\begin{tabular}{cc}
\hline Dimensions & Cronbach alpha \\
\hline Usefulness & $\alpha=0.91$ \\
\hline Difficulty & $\alpha=0.80$ \\
\hline Safety & $\alpha=0.76$ \\
\hline Attractiveness & $\alpha=0.71$ \\
\hline
\end{tabular}

\section{METHODOLOGY}

\section{Respondents}

The study is focused on misconceptions in genetic therefore respondents which attended genetics course were chose. Students of third or fourth grade just have passed genetics course in Czech Republic. The study was conducted with a sample of 102 students in the eleventh grade (17 - 18 years old). Respondents were from four classes of two high schools. There were 35 women and 67 men, 81 of which were atheists and 21 who had religious backgrounds, 19 students with final exam score 1, 44 students with final exam score 2 and 39 students with final exam score 3 . All included that the students passed one year of genetics education.

\section{Research Tool}

The research tool consisted of two parts. Demographic items were at the beginning of the research tool (gender, religiosity and success in biology). Second part was created by items of semantic differential. Items of semantic differential are presented as Appendix A. Research tool created by Bauer (2011) was an inspiration for the second part of the research in this study. This part included 27 points' pairs of adjectives. Semantic differential is especially suitable for measuring emotional and behavioural aspects of a person's attitude (Perkins, Hughey \& Speer 2002). Each scale was significantly saturated by one factor. Scales were written from positive to negative (11 scales) with adjectives and in reverse order ( 9 scales). Research tool were administered by authors of the research. Completing of the research tool took an average of 5 to 10 minutes.

\section{Data Analysis}

Demographic characteristics were deliberated to be independent variables. Independent variable success in biology was delivered from the individual's final exam in biology. This independent variable was used to confirm the validity of the study criteria. Second part of the research tool was considered to be a dependent variable. Data gained from respondents were converted into numerical form. The low score indicated negative attitudes and the highest scoring point to positive attitude. Neutral attitudes were expressed by number in the middle of the scale (3), the most positive attitudes were presented by number 7 and the negative attitudes were indicated by number 1.

Kolmogorov-Smirnov test was applied to discover the normality of data $(d=0.06 p>0.20)$. Result of Kolmogorov-Smirnov test allowed us to apply the parametric method. Reliability of data was determined by Cronbach alpha $(\alpha=0.81)$. Results showed sufficient reliability of data (Nunnally 1978). Reliability of each of the four dimensions of semantic differential did not decrease under value 0.71 . These results are presented in Table 1.

For verifying possibility to use factor analysis were used Kaiser-Meyer-Olkin test and Bartlett test. Value of KMO test was determined 0.79 and value of Bartlett test of sphericity was $\chi^{2} 1072.71 ; p<0.001$ ). These results determine suitability of factor analysis. Factor analysis was applied for distributing scales of semantic differential to factors. One factor is created by minimally three scales. Ascertained dimensions were "Usefulness of genetics" (6 scales included: 2, 10, 16, 17, 19), "Difficulty of genetics" (5 scales included: 1, 4, 5, 7, 8, 11), "Safety of genetics" (4 scales included: 13, 14, 15, 18) and "Attractiveness of genetics" (5 scales included: 3, 6, 9, 12, 20). The names of dimensions were created according the scales, which were included in the dimension. For example dimension called "Attractiveness of genetics" included scales containing adjectives, which precisely described, what it does genetics attractively for pupils. Results of factor analysis are presented in Table 2.

The descriptive method (mean) and the inferential method (ANOVA) were applied. In case of independent variable achievement in biology the Tukey post-hoc test was used to reveal particular statistical substantial difference. 
Table 2. Results of factor analysis

\begin{tabular}{|c|c|c|c|c|}
\hline \multicolumn{5}{|l|}{ I Usefulness of genetics } \\
\hline meaningless - useful & 0.67 & -0.07 & -0.06 & 0.31 \\
\hline valuable - useless & 0.73 & -0.03 & 0.06 & 0.33 \\
\hline beneficial - purposeless & 0.92 & -0.09 & -0.01 & 0.11 \\
\hline important - insignificant & 0.88 & -0.04 & 0.04 & 0.08 \\
\hline unnecessary - helpful & 0.84 & 0.06 & 0.03 & 0.21 \\
\hline \multicolumn{5}{|l|}{ II Difficulty of genetics } \\
\hline easy - difficult & 0.03 & 0.79 & -0.16 & 0.08 \\
\hline complicated - simple & -0.03 & 0.76 & 0.03 & -0.13 \\
\hline confusing - clear & 0.00 & 0.75 & -0.01 & 0.20 \\
\hline frightening - cheerful & 0.28 & 0.41 & 0.01 & 0.38 \\
\hline unfathomable - comprehensible & -0.13 & 0.81 & 0.15 & 0.15 \\
\hline laborious - undemanding & -0.30 & 0.67 & 0.25 & -0.19 \\
\hline \multicolumn{5}{|l|}{ III Safety of genetics } \\
\hline harmless - dangerous & -0.08 & -0.10 & 0.83 & -0.03 \\
\hline stressful - relaxed & 0.29 & 0.32 & 0.49 & 0.04 \\
\hline risky - protecting & -0.04 & 0.02 & 0.88 & 0.07 \\
\hline safe - hazardous & 0.05 & 0.04 & 0.78 & 0.07 \\
\hline \multicolumn{5}{|l|}{ IV Attractiveness of genetics } \\
\hline exciting - boring & 0.12 & 0.05 & 0.03 & 0.79 \\
\hline good-bad & 0.30 & 0.11 & 0.12 & 0.73 \\
\hline interesting - monotonous & 0.34 & -0.03 & 0.15 & 0.68 \\
\hline chaotic - organized & 0.08 & 0.39 & -0.13 & 0.44 \\
\hline noteworthy - ordinary & 0.35 & -0.08 & -0.01 & 0.50 \\
\hline Eigenvalue & 5.52 & 3.55 & 2.38 & 1.22 \\
\hline$\%$ of variance & 27.63 & 17.75 & 11.92 & 6.12 \\
\hline
\end{tabular}

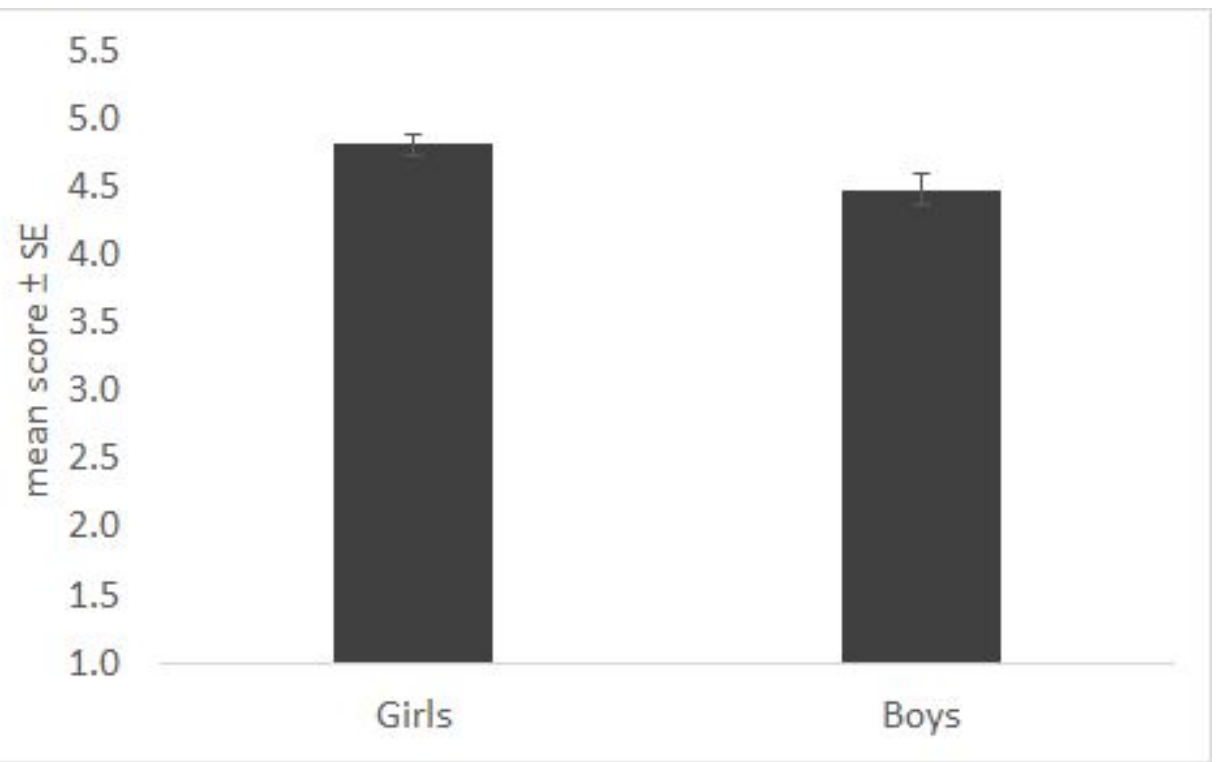

Figure 1. Influence of gender according to overall mean score

\section{RESULTS}

\section{Mean Score According to Independent Variables}

The overall attitude to genetics was $4.71(\mathrm{SE}=0.10)$. General attitude to genetics among girls was $(\mathrm{x}=4.82, \mathrm{SE}$ $=0.08)$ and among boys $(\mathrm{x}=4.49, \mathrm{SE}=0.11)$. Gender was confirmed to be a statistically significant variable influencing attitudes to genetics $(\mathrm{F}=5.70, \mathrm{p}<0.05)$ (Figure 1). 


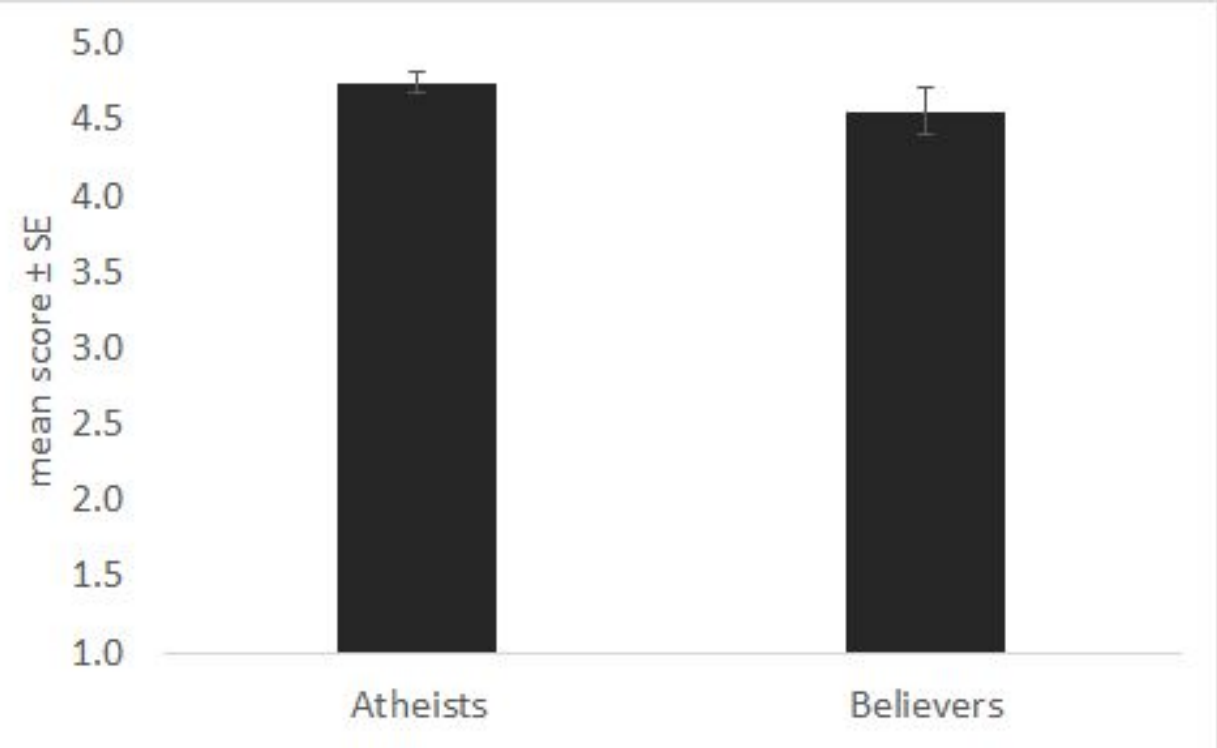

Figure 2. Influence of religiosity according to overall mean score

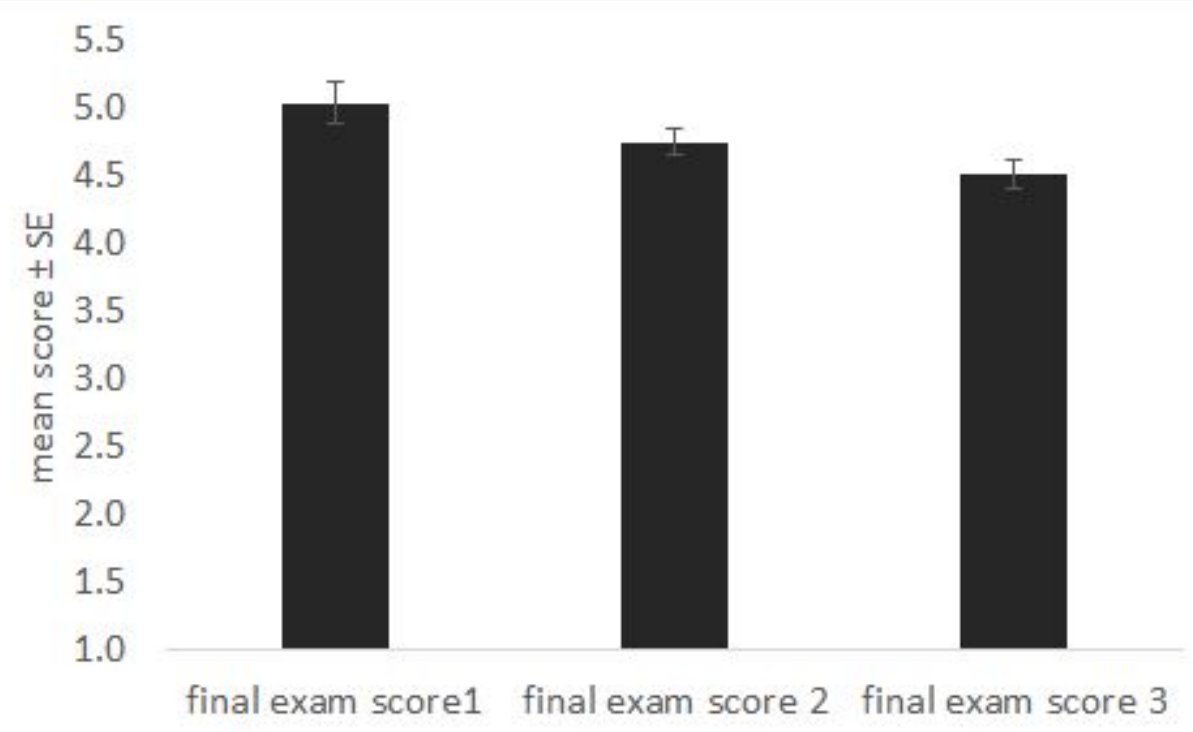

Figure 3. Influence of success in biology according to overall mean score

Atheists gained a mean score of $\mathrm{x}=4.75(\mathrm{SE}=0.07)$ and religious people achieved a score of $4.56(\mathrm{SE}=0.15)$. Results did not demonstrate statistically significant influence based on religiosity $(F=1.27, p=0.26)$ (Figure 2).

Students with a final exam score of 1 gained score $\mathrm{x}=5.04(\mathrm{SE}=0.15)$, students with a final exam score of 2 reached score $x=4.75(\mathrm{SE}=0.10)$, students with a final exam score of 3 had a mean score $4.52(\mathrm{SE}=0.11)$. Independent variable success in biology was discovered to be a statistically significant variable effecting attitudes to genetics $(\mathrm{F}=3.31, \mathrm{p}<0.05)$. Students with better final exams from biology showed more positive attitudes toward genetics. Results are presented in Figure 3.

Mean score and standard error according to independent variables is presented in Table 3. 
Table 3. Mean score and standard deviation according to independent variable

\begin{tabular}{|c|c|c|c|}
\hline Independent variable & & Mean score & Standard error \\
\hline \multirow{2}{*}{ Gender } & Girls & 4.82 & 0.08 \\
\hline & Boys & 4.49 & 0.11 \\
\hline \multirow{2}{*}{ Religiosity } & Atheists & 4.75 & 0.07 \\
\hline & Religious people & 4.56 & 0.15 \\
\hline \multirow{3}{*}{ Success in biology } & Final exam score 1 & 5.04 & 0.15 \\
\hline & Final exam score 2 & 4.75 & 0.10 \\
\hline & Final exam score 3 & 4.52 & 0.11 \\
\hline
\end{tabular}

Table 4. Overall score and mean score and standard error according to dimensions

\begin{tabular}{ccc}
\hline & Mean score & Standard error \\
\hline Overall score & 4.71 & 0.71 \\
\hline Dimension Usefulness & 5.82 & 1.13 \\
\hline Dimension Difficulty & 3.71 & 1.11 \\
\hline Dimension Safety & 4.38 & 1.09 \\
\hline Dimension Attractiveness & 5.05 & 1.05 \\
\hline
\end{tabular}

\section{Results According to Dimension}

The most positive attitudes were identified in dimension "Usefulness" $(x=5.82, S E=1.13)$. Overall attitudes in dimension "Attractiveness" were $x=5.05(\mathrm{SE}=1.05)$. Dimension "Safety revealed mean score $\mathrm{x}=4.38(\mathrm{SE}=1.09)$. Only dimension "Difficulty" showed attitudes under neutral score $(x=3.71, \mathrm{SE}=1.11)$. Overall score and mean score for particular dimensions and standard error is summarised in Table 4.

\section{Influence of Independent Variables on the Dimensions}

\section{Dimension "Usefulness"}

Gender had not got statistically significant influence on results $(F=1.91, p=0.17)$. Girls achieved a mean score $x=5.92(\mathrm{SE}=0.14)$ and boys achieved a mean score $\mathrm{x}=5.60(\mathrm{SE}=0.19)$. The independent variable religiosity was not detected to be a statistically significant variable in this dimension $(F=1.17, p=0.28)$. Atheists reached mean score $\mathrm{x}=5.87(\mathrm{SE}=0.12)$ and religious people reached a mean score $5.58(\mathrm{SE}=0.26)$. The last independent variable was success in biology which showed detected to be statistically significant $(\mathrm{F}=2.94, \mathrm{p}<0.05)$. This significant difference was between students with final exam score of 1 , final exam score of 3 , between students with final exam score of 1 and final exam score of 4 . In all cases more positive attitudes were detected among students with final exam score of 1 . Students with a final exam score of one gained a mean score $x=6.11(\mathrm{SE}=0.22)$, students with a final exam score of two gained a mean score $\mathrm{x}=5.91(\mathrm{SE}=0.16)$, students with a final exam score of three gained a mean score $5.66(\mathrm{SE}=0.18)$.

\section{Dimension "Difficulty"}

There were no gender differences in the dimension $(\mathrm{F}=0.37, \mathrm{p}=0.55)$. Girls achieved a mean score $\mathrm{x}=3.66(\mathrm{SE}$ $=0.14)$ and boys achieved a mean score $\mathrm{x}=3.80(\mathrm{SE}=0.18)$. There were no religiosity differences in the dimension $(\mathrm{F}=0.14, \mathrm{p}=0.71)$. Both atheists $(\mathrm{x}=3.73, \mathrm{SE}=0.12)$ and religious people $(\mathrm{x}=3.63, \mathrm{SE}=0.24)$ received similar scores. The last variable success in biology was not identified to be statistically significant in this dimension $(\mathrm{F}=$ $1.32, p=0.27)$. Students with a final exam score of one reached a mean score $x=4.08(S E=0.25)$, students with a final exam score of two reached a mean score $x=3.74(\mathrm{SE}=0.17)$, students with a final exam score of three reached a mean score $\mathrm{x}=3.51(\mathrm{SE}=0.18)$.

\section{Dimension "Safety"}

Statistically significant influence of gender was revealed in this dimension $(F=5.75, p<0.05)$. Higher score were achieved by girls $(x=4.56, \mathrm{SE}=0.13)$ compared to boys $(x=4.03, \mathrm{SE}=0.18)$. The independent variable religiosity was not statistically significant $(F=0.33, p=0.56)$. Atheists reached a mean score $x=4.35(S E=0.12)$ and religious people reached score $\mathrm{x}=4.50(\mathrm{SE}=0.24)$. The last determined variable was success in biology and this dimension was not statistically significant $(F=1.01, p=0.40)$. Students with final exam score of one gained a mean 
score $x=4.58(\mathrm{SE}=0.25)$, students with a final exam score of two gained a mean score $\mathrm{x}=4.28(\mathrm{SE}=0.16)$, students with a final exam score of three gained a mean score $\mathrm{x}=4.32(\mathrm{SE}=0.18)$.

\section{Dimension "Attractiveness"}

Variable gender was determined to be statistically significant in this dimension $(\mathrm{F}=11.78, \mathrm{p}<0.05)$. Girls achieved a higher score $(x=5.30, \mathrm{SE}=0.12)$ than boys $(x=4.58, \mathrm{SE}=0.17)$. Girls received higher score $(\mathrm{x}=5.30$; $\mathrm{SE}$ $=0.12)$ in the dimension attractiveness than boys $(\mathrm{x}=4.58 ; \mathrm{SE}=0.17)(\mathrm{F}=11.78 ; \mathrm{p}<0.05)$. The next variable religiosity was statistically significant $(\mathrm{F}=4.66, \mathrm{p}<0.05)$. Atheists gained a mean score $\mathrm{x}=5.17(\mathrm{SE}=0.11)$ and atheists gained a mean score $\mathrm{x}=4.62(\mathrm{SE}=0.23)$. The independent variable success in biology was not revealed to be statistically significant $(F=2.60, p=0.056)$. Students with a final exam score of one achieved a mean score $x=$ $5.45(\mathrm{SE}=0.24)$, students with final exam score of two achieved mean score $\mathrm{x}=5.17(\mathrm{SE}=0.15)$, students with a final exam score of three achieved a mean score $x=4.76(\mathrm{SE}=0.17)$.

\section{DISCUSSION}

The first research question was: "What is general students' attitudes to genetics?" The overall attitude to genetics was identified to be slightly positive. Similar results were gained by Bal, Samancı \& Bozkurt (2007). The positive attitudes toward genetics are possibly caused by positive perception of topics regarding to genetics in comparison with other biological topics like Cimer (2012) quoted. Including many other authors like Massarani \& Moreira (2005) who detailed positive attitudes toward genetics among high school students in Brazil. The positive attitudes could be connected with the relatively good kinds of information about some of the main issues from genetics (like transcription of DNA and others). And many of these kinds of facts could be learned from other sources like educational materials and curriculum material. This should be considered with the background of the formal science educational system, which is frequently inefficient and outdated (see also Massarani \& Moreira 2005). This suggested that other factors - different from the school curriculum science - may have a strong influence on the formation of the attitudes of students. There are many possibilities, on how to collect information about anything in the world and compare it with the school's curriculum. It could also cause many students to have more benevolent and challenging opinions on the use of genetics on human beings and their overall attitudes show to be more and more positive.

The slightly positive attitudes could be caused by the better knowledge of pupils about different genetic concepts. The genetics belongs among progressive and quickly developing disciplines (Iida 2015), with the increasing lesson dotation in curriculum. On the basis of this fact, the pupils are confronted with higher amount of curriculum and it could have the impact on the level of attitudes toward genetics as school subject. The similar positive relationship between knowledge and attitudes was investigated in the studies of Olwi, Merdad \& Ramadan (2016) or Rzymski \& Krolczyk (2016). Also the effect of teacher is important, because pupils support such things and facts, which are understandable for them. If teachers are explaining genetics topics in interesting way, it could improve the level of interest about topic, the similar mention is in the study of Erdogan et al. (2012).

The second research question was: "Is there an influence based on gender to the attitude of genetic research?" Gender seems to be a significant factor influencing attitudes to genetics in some situations, girls achieved statistically significant higher score in comparison with boys. The research studies regarding to similar problematic showed inconsistent results. Some studies are in the concordance with our results and some produced different results. Similar results were presented by Aro et al. (1997). With respect to safety and attractiveness girls revealed more positive attitudes than boys. Napolitano \& Ogunseitan (1999) published different result in the similar research. Men held a better attitude toward genetic engineering in comparison to women. Authors showed, it is possibly caused by the higher fear that women have about their future life and children. Many authors quoted, is there some concrete genetic concept which is examined, the attitudes toward it is are not in the favour of women, but in the favour of men or are they similar. Also Prokop et al. (2007) and Usak et al. (2009) referred about a more positive attitude regarding boys toward biotechnology and genetically modified organisms. In the general view of genetics women (girls) achieved higher scores and had much more positive attitudes toward this concept in comparison with boys. For example Kopesky et al. (2011) found out, that knowledge of both gender in genetics is equal, but females reported greater interest in pursuing a career in genetic counselling, they also rated interpersonal aspects as more integral to genetic counselling work.

Females also rated very high interpersonal aspects, which are connected with possible future work, where genetics is the main area and females are more accustomed to a greater extent than males in pursuing nurturing/care-giving careers. The similar approach was possible to find in the studies of Rolfe (2006) and Simpson (2005). In our research girls achieved higher score, it could be caused by the connection of genetics with human body and as Jones, Howe \& Rua (2000) quoted, that these topics (related to human body) are better perceived by girls than boys. 
The third research question was: "Is there an influence based on religiosity to the attitude of genetic research?" Other variable influencing attitudes to genetics just in some occasions is religiosity. Precisely, attractiveness is aspect of genetics where atheists had a more positive attitudes to genetics then non atheists. Another similar result was possible to find in the study of Grosschedl, Konnemann \& Basel (2014) or Siani \& Assaraf (2015). Also Allum et al. (2014) they found out that Catholics, as well as those who attend church often, were less likely to support the genetic testing of unborn babies. Those who adhered to creationist beliefs were less optimistic about the prospects held out for the future by developments in genetic medicine. Also strongly religious people who were also highly knowledgeable about science tended to had more negative attitudes to genetic testing than those who were less scientifically literate. It is relatively straight forward, why religious people are refusing things connected with genetics. They are influenced by the many aspects of their religiosity, which are in many cases dogmatic and refuse the new things like genetics.

Last research question was connected with success of students in school and attitudes toward genetics. Our result showed that students with better final exam score had got more positive attitudes toward genetics. The similar result was possible to find out also in other research studies; however not one person's studies were regarding to genetics. Koksal \& Mustafa (2007) showed similar results in the topic "Respiratory system". Also Armbruster et al. (2009) found out positive relationships between success of a student and their attitudes towards biology. This relationship is awaited, because students, who are more successful in any school subject, manifest a higher level of interest pertaining to the knowledge connected with genealogy. This can lead to higher attitudes toward any other type of phenomenon, in the case of genetics.

Hansen \& Birol (2014) found out also positive relationship between attitudes to biology and achievement. However as authors wrote, the positive relationship is possible to find in later year of study, not in the beginning of the biology program. At the beginning of biology program had got respondents similar attitudes with respect to their achievement. But at the end of program the attitudes are changing, students with better achievement had got more positive attitudes in comparison with students with worse achievement. It means, when pupils are familiar with the curriculum of genetics and they are "experts" in this field, they attitudes and also achievement is changing and then is possible to find relationship between these two variables. The most influencing factor was their determined success in biology. This factor was significant in all overall attitudes to genetics. In this case students with a final exam score of one had a more positive attitude to genetics compared to students with a final exam score of 3. When referring to dimensions, success in biology was statistically a significant factor in dimension difficulty. Statistically significant difference was between students with a final exam score of 1 , students with a final exam score of 3 . When we look at all these results according to dimension data and biology. We can see that attitudes always decreased with decreasing grade scores. This is a parallel relationship between educations and awareness to genetics.

Concerning dimensions the lowest mean score was detected in dimension difficulty. When we compare average attitudes according to independent variables from this dimension with others, we can inquire about the lowest mean scores. Difficulty can be deemed as a seriously decreasing attitude to genetics. The next dimension is a decrease to attitudes when genetics was determined to be safe. Difficulty means problems, confusing information or unintelligibility and safety means tension, risk or gamble. These aspects negative influence on attitudes to genetics shocks. Jallinoja \& Aro (2000) discovered similar findings. In spite of approval perform genetic testing, respondents were worried about some problems connected with this topic. Furthermore, Jallinoja \& Aro (2000) discovered a influence on the amount of knowledge based on attitudes. These finding led to dimension difficulty. Authors declared problems with the creation of stance based on less informed people. People or students with less knowledge probably consider genetics more difficult and thus they cannot find their own stance. Other authors Bal, Samanc1 \& Bozkurt (2007) claimed that when we raise the amount of knowledge attitudes to genetics will migrate to the positive side.

On the other side, dimensions usefulness and attractiveness lead to more positive attitudes. It seems that usefulness expressed by helpfulness, importance or necessity and attractiveness expressed by exactness, heterogeneity or extraordinariness lead to more positive attitudes to genetics.

\section{CONCLUSION}

Genetics is one of the world's most progressive and current fields of science. Ethical aspects, social aspects and other controversy topics connect with genetics and should be tested. It is necessary to inform the general public about issues concerning genetics. The best place where to improve awareness is school. Pupils and students should be debating these controversial topics. Teachers should outline the urge and importance of genetics and genetic testing. The genetics curriculum should be restructured and focused on these real principles. Pupils and students ought to be lead in making ethical and moral decisions with respect to their attitudes. Better knowledge and also better genetic literacy will achieve and improve the incorporation of cooperative and inquiry based learning. As Gilliens \& Nichols (2015) stated, teachers found out that cooperative learning was a driver for inquiry. This also 
encouraged pupils to take ownership of their learning process. The teachers also appreciated the opportunity to be creative in the way they taught so the students were engaged in discussing real world topics which made their learning meaningful. However, the teachers did emphasise that this was important to them to structure the inquiry process. This challenged students' thinking and constructed their learning to encourage discussion. Similarly Tseng, Tuan \& Chin (2013) reported that the very experienced teachers claimed that their persistence in implementing inquiry science in their classrooms was due to their positive experiences in inquiry during their own learning.

This study highlight specific aspect of genetic education which is connected with attitudes, moral and ethical issues. Zande (2009) alert to absence of reflection on moral reasoning in biological curriculum. According to this study students need empower for dealing with future moral dilemmas connected with genetics. Incoming studies should focused on finding ways how to lead students to more scientific reasoning in genetic-related issues and prepare them to real life. Many researches examine misconceptions in genetics. Attitudes to genetics and ethical aspect of genetics seem to be less explored. These mentioned topics can be closely interconnected, thus it can be new topic for research.

\section{REFERENCES}

Allum, N., Sibley, E., Sturgis, P., \& Stoneman, P. (2014). Religious beliefs, knowledge about science and attitudes towards medical genetics. Public Understanding of Science, 23(7), 833-849.

Armbruster, P., Patel, M., Johnson, E., \& Weiss, M. (2009). Active learning and student-centered pedagogy improve student attitudes and performance in introductory biology. CBE - Life Sciences Education, 8(3), 203-213.

Aro, A. R. et al. (1997). Acceptance of genetic testing in a general population: Age, education and gender differences. Patient Education and Counselling, 32(1-2), 41-49.

Bahar, M., Johnstone, A. H., \& Hansell, M. H. (1999). Revisiting learning difficulties in biology. Journal of Biological Education, 33(2), 84-86.

Bahri, N. M., Suryawati, E., \& Osman, K. (2014). Students' biotechnology literacy: The pillars of STEM education in Malaysia. Eurasia Journal of Mathematics, Science E Technology Education, 10(3), 195-207.

Bal, Ş., Samanc1, N. K., \& Bozkurt, O. (2007). University students' knowledge and attitude about genetic engineering. Eurasia Journal of Mathematics, Science \& Technology Education, 3(2), 119-126.

Bauer, C. F. (2008). Attitude toward chemistry: a semantic differential instrument for assessing curriculum impacts. Journal of Chemical Education, 85(10), 1440-1445.

Ceyhan, B., \& Sahin, N. (2015). Are pre-service science teachers' ethical views on genetic issues affected by their moral values? Procedia - Social and Behavioral Sciences, 186, 137-142.

Chabalengul, V. M., Mumba, F., \& Chitiyo, J. (2011). American elementary education pre-service teachers' attitudes towards biotechnology processes. International Journal of Environmental \& Science Education, 6(4), 341-357.

Cimer, A. (2012). What makes biology learning difficult and effective: Students' views. Educational Research and Reviews, 7(3), 61-71.

Eagly, A., \& Chaiken, S. (1998). Attitudes structure and function. In D. T. Gilbert, S. T. Fiske, G. Lindzey (Ed.), The handbook of social psychology (pp. 269-322). New York: McGraw-Hill.

Erdogan, M., Ozel, M., BouJaoude, S., Lamanauskas, V., Uşak, M., \& Prokop, P. (2012). Assessment of preservice teachers' knowledge of and attitudes regarding biotechnology: A cross-cultural comparison. Journal of Baltic Science Education, 11(1), 78-93.

Evans, G., \& Durant, J. (1995). The relationship between knowledge and attitudes in the public understanding of science in Britain. Public Understanding of Science, 4(1), 57-74.

Finley, F. N., Stewart, J., \& Yarroch, W. L. (1982). Teachers' perceptions of important and difficult science content. Science Education, 66(4), 531-538.

Gili, M. (2001). Attempting to break the code in student comprehension of genetic concepts. Journal of Biological Education, 35(4), 183-190.

Gillies, R. M. \& Nichols, K. (2015). How to support primary teachers' implementation of inquiry: Teachers' reflections on teaching cooperative inquiry-based science. Research in Science Education, 45(2), 171-191.

Grosschedl, J., Konnemann, C., \& Basel, N. (2014). Pre-service biology teachers' acceptance of evolutionary theory and their preference for its teaching. Evolution: Education and Outreach, 7(18), 1-16.

Gul, S., \& Sozbilir, M. (2015). Biology education research trends in Turkey. Eurasia Journal of Mathematics, Science E Technology Education, 11(1), 93-109. 
Hansen, M. J., \& Birol, G. (2014). Longitudinal study of student attitudes in a biology program. CBE - Life Sciences Education, 13(2), 331-337.

Hidi, S. (2006). Interest: A unique motivational variable. Educational Research Review, 1(2), 69-82.

Iida, K. (2015). Genetics and 'breeding as a science': Kihara Hitoshi and the development of genetics in Japan in the first half of the twentieth century. In D. Phillips and S. Kingsland eds. New Perspectives on the History of Life Sciences and Agriculture (Archimedes 40, Springer International Publishing Switzerland), pp. 439-458.

Jallinoja, P., \& Aro, A. R. (2000). Does knowledge make a difference? The association between knowledge about genes and attitudes toward gene tests. Journal of Health Communication, 5(1), 29-39.

Jones, M. G., Howe, A., \& Rua, M. (2000). Gender differences in students' experiences, interests, and attitudes toward science and scientists. Science Education, 84(2), 180-192.

Jurkiewicz, A., Zagorski, J., Bujak, F., Lachowski, S., \& Florek-Łuszczki, M. (2014). Emotional attitudes of young people completing secondary schools towards genetic modification of organisms (GMO) and genetically modified foods (GMF). Annals of Agricultural and Environmental Medicine, 21(1), 205-211.

Koksal, M. S., \& Mustafa, Y. (2007). The effect of multiple intelligences theory (MIT)-based instruction on attitudes towards the course, academic success, and permanence of teaching on the topic of "Respiratory systems.". Educational Sciences: Theory E Practice, 7(1), 231-239.

Kopesky, J. W., Veach, P. M., Lian, F., \& LeRoy, B. S. (2011). Where are the males? Gender differences in undergraduates' interest in and perceptions of the genetic counseling profession. Journal of Genetic Counseling, 20(4), 341-354.

Lanie, A. D., Jayaratne, T. E., Sheldon, J. P, Kardia, S. L. R., Anderson, E. S. \& Feldbaum, M. (2004). Exploring the Public Understanding of Basic Genetic Concepts. Journal of Genetic Counseling, 13(4), 305-320.

Massarani, L., \& Moreira, I. C. (2005). Attitudes towards genetics: a case study among Brazilian high school students. Public Understanding of Science, 14(2), 201-212.

Morgan, C. T. (1961). Introduction to psychology. New York: McGraw-Hill Rook Co.

Napolitani, C. L., \& Ogunseitan, O. A. (1999). Gender differences in the perception of genetic engineering applied to human reproduction. Social Indication Research, 46(2), 191-204.

Nunnally, J. C. (1978). Psychometric theory. New York: McGraw-Hill.

Olwi, D., Merdad, L., \& Ramadan, E. (2016). Knowledge of genetics and attitudes toward genetic testing among college students in Saudi Arabia. Public Health Genomics, 19(5), 260-268.

Perkins, D. D., Hughey, J., \& Speer, P. W. (2002). Community psychology perspectives on social capital theory and community development practice. Journal of the Community Development Society, 33(1), 33-52.

Prokop, P., Leskova, A., Kubiatko, M., \& Diran, C. (2007). Slovakian students' knowledge of and attitudes toward biotechnology. International Journal of Science Education, 29(7), 895-907.

Ratcliffe, M. \& Grace, M. (2003). Science Education for Citizenship, Teaching Socio-Scientific Issues. MaidenheadPhiladelphia: Open University Press.

Rolfe, H. (2006). Where are the men? Segregation in the childcare and early years sector. National Institute Economic Review, 195(1), 103-117.

Rzymski, P., \& Krolczyk, A. (2016). Attitudes toward genetically modified organisms in Poland: to GMO or not to GMO? Food Security, 8(3), 689-697.

Saka, A., Cerrah, L., Akdeniz, A. R., \& Ayas, A. (2006). A Cross-Age Study of the Understanding of Three Genetics Concepts: How Do They Image the Gene, DNA and Chromosome? Journal of Science Education and Technology, 15(2), 192-202.

Shea, N. A., Duncan, R. G., \& Stephenson, C. (2015). A tri-part model for genetics literacy: Exploring undergraduate student reasoning about authentic genetics dilemmas. Research in Science Education, 45(4), 485-507.

Siani, M., \& Assaraf, O. B. (2015). University students' attitudes towards genetic testing: A comparative study. American Journal of Public Health Research, 3(3), 81-90.

Simpson, R. (2005). Men in non-traditional occupations: career entry, career orientation and experience of role strain. Gender, Work and Organization, 12(4), 363-380.

Sorgo, A., Usak, M., Kubiatko, M., Fancovicova, J., Prokop, P., Puhek, M., et al. (2014). A cross-cultural study on freshmen's knowledge of genetics, evolution, and the nature of science. Journal of Baltic Science Education, 13(1), 6-18.

Tseng, C., Tuan, H., \& Chin, C. (2013). How to help teachers develop inquiry teaching: perspectives from experienced science teachers. Research in Science Education, 43(2), 809-825. 
Usak, M., Erdogan, M., Prokop, P., \& Ozel, M. (2009). High school and university students' knowledge and attitudes regarding biotechnology. Biochemistry and Molecular Biology Education, 37(2), 123-130.

Van der Zande, P., Brekelmans, M., Vermunt, J. D. \& Waarlo, A. J. (2009). Moral reasoning in genetics education. Journal of Biological Education, 44(1), 31-36.

\section{APPENDIX A}

\section{Items of Semantic Differential}

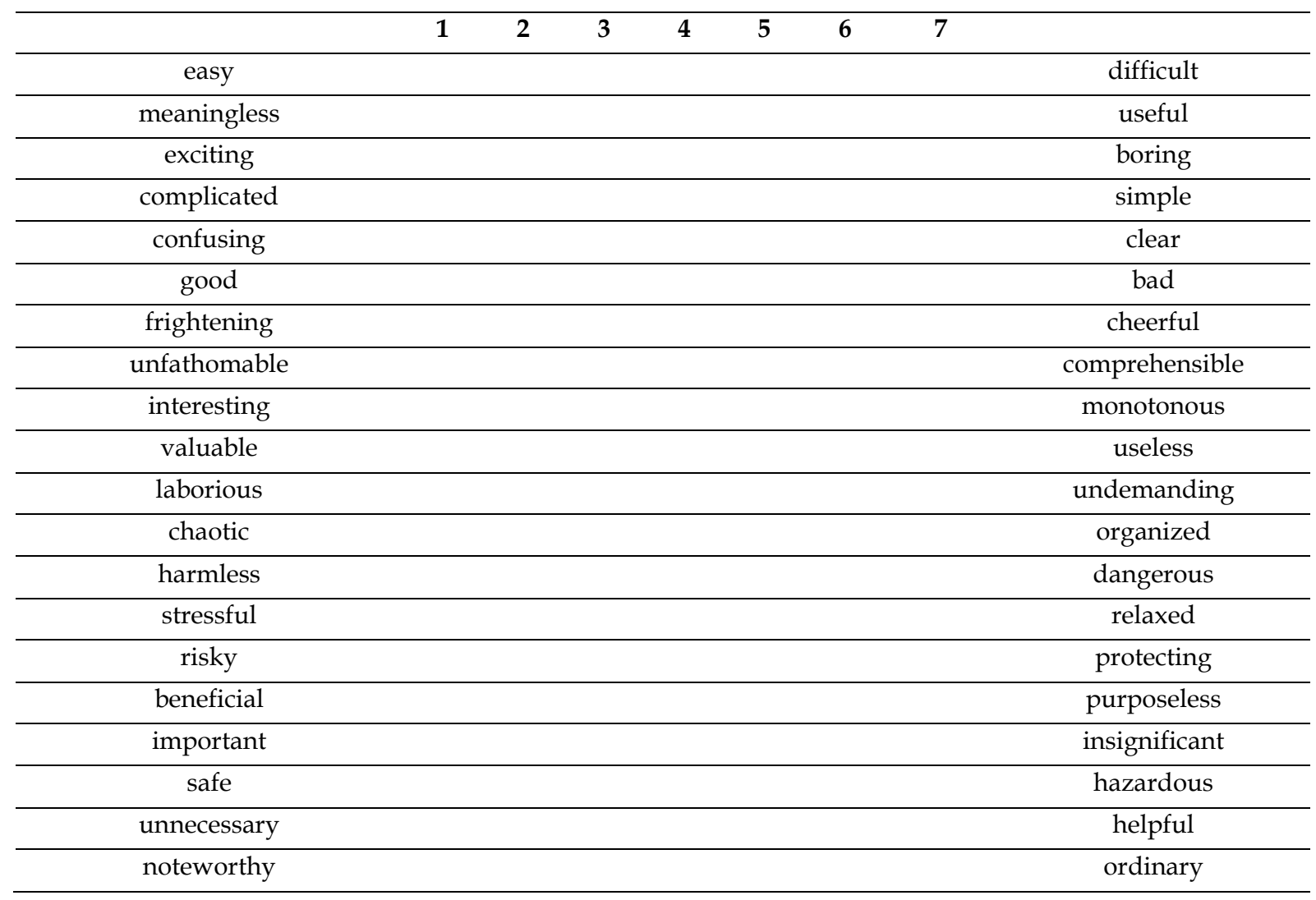

\section{http://www.ejmste.com}

